\title{
ЦИТ: иа217-070
}

DOI: $10.21893 / 2415-7538.2017-06-3-070$

УДК 378.147:373.2.011.3-051]:17.022.1

ПРОФЕСІЙНИЙ ІМІДЖ ВИХОВАТЕЛЯ ДОШКІЛЬНОГО

Марєєва Т. В.

НАВЧАЛЬНОГО ЗАКЛАДУ ТА ЙОГО СТРУКТУРА

Глухівський начіональний педагогічний університет імені Олександра Довженка,

Глухів, Києво-Московська 24, 41400

Maryeyeva T. V.

\section{PRE-SCHOOL EDUCATIONAL INSTITUTION TEACHERS' PROFESSIONAL IMAGE AND ITS STRUCTURE \\ Oleksandr Dovzhenko Hlukhiv National Pedagogical University \\ Hlukhiv, Kyevo-Moskovska 24, 41400}

Анотація. У статті здійснено аналіз тлумачення понять «імідж» $i$ «педагогічний імідж»; розглянуто сутність професійного педагогічного іміджу, іміджу вихователя дошкільного навчального закладу. Розкрито структурні компоненти професійного іміджу вихователя дошкільного навчального закладу та їх взаємозв'язок.

Ключові слова: імідж, професійний імідж, педагогічний імідж, вихователь дошкільного навчального закладу.

Abstract. In the article author analyzes the interpretation of the concept of "image" and "pedagogical image", describes the essence of the professional pedagogical image, pre-school educational institution teacher's image. The structural components of pre-school educational institution teacher's professional image and their correlation were revealed in the article.

Key words: image, professional image, pedagogical image, pre-school educational institution teacher.

Вступ. Нинішній етап розвитку нашої країни позначений інтеграцією в європейський освітній простір, що спричиняє низку перетворень у всіх ланках вітчизняної освіти. 3 огляду на це особливої актуальності набувають модернізаційні процеси в професійній підготовці вихователів дошкільних навчальних закладів (далі ДНЗ), що відображають вимоги до педагогів з боку споживачів освітніх послуг (дітей та їхніх батьків), громадськості. Тому дедалі більшого значення набуває здатність вихователів до підвищення рівня фахової майстерності, самовдосконалення, побудови позитивного професійного іміджу, який великою мірою створює i репрезентує загальний імідж дошкільної установи. Тому дедалі більшого значення набуває здатність вихователів до підвищення рівня фахової майстерності, самовдосконалення, побудови позитивного професійного іміджу, який великою мірою створює і репрезентує загальний імідж дошкільної установи.

Основний текст.

Аналіз останніх публікацій. Проблема іміджу, іміджології та іміджування - процесу створення або конструювання іміджу - почала цікавити наукову 
громадськість із другої половини XX - початку XXI століття. У цей час починають 3'являтися праці із безпосереднім уживанням і тлумаченням поняття «імідж», роз'ясненням способів його створення. Спочатку такі наукові розвідки здійснюються в Європі і США (Б.Андерсон, К.Боулдінг, С.Вільямс, Дж.Груніг, Ф.Джефкінс, М.Моффіт, Л.Робертс та ін.), а з кінця XX - на початку XXI століття й в Україні та близькому зарубіжжі (Н.Барна, Л.Данильчук, Г.Дідух, О.Змановська, А.Калюжний, О.Панасюк, О.Перелигіна, О.Петрова, Г.Почепцов, В.Шепель, С.Яндарова та ін.).

Віднедавна почав зростати інтерес до педагогічної іміджології - наукового напряму, що займається розробленням і застосуванням теорії та практики формування іміджу педагогічних працівників, освітніх закладів, іміджу системи освіти. Деякі означені проблеми висвітлені у працях, що стосуються специфіки і шляхів створення іміджу освітньої, зокрема дошкільної установи (Л.Даниленко, К.Крутій, Т.Піскунова та ін.), формуванню педагогічного іміджу та «професійного образу Я» чинного і майбутнього педагога (О.Горовенко, Н.Гузій, О.Ковальова, А.Кононенко, Т.Марєєва, Ж.Попова, В.Стрельніков, А.Череднякова та ін.), професійного іміджу викладача вищої школи (Т.Бусигіна, Л.Донська, В.Ісаченко, О.Попова та ін.), професійного іміджу вихователя ДНЗ (М.Апраксіна, Л.Загородня, К.Крутій, С.Попиченко, Р.Шулигіна та ін.). Проте системних досліджень, присвячених проблемі професійного іміджу вихователя ДНЗ, його типів і структури, способів його створення не здійснено.

Мета статті: 1) здійснити аналіз досліджень, присвячених проблемі іміджу педагога; 2) розкрити сутність професійного педагогічного іміджу, іміджу вихователя ДНЗ та його структуру.

Виклад основного матеріалу. Аналіз літературних джерел із суміжних 3 іміджологією галузей знань (політології, соціології, менеджменту, маркетингу) показав, що у цих науках вироблено низку визначень поняття «імідж», котрі вирізняються синтезом різнорідних фактів, з одного боку, і недостатнім рівнем узагальнення та вузькою спеціалізованістю, з іншого.

Так, наприклад, дослідники політичного лідерства називають іміджем систему оптимально дібраних характеристик кандидата, котра ефективно впливає на електорат і спрямована на отримання максимальної кількості голосів на виборах (Ж.Блондель, Ф.Ільясов, Л.Шибут та ін.). Часто такі характеристики, на думку американського політолога Р.Дентона, люди асоціюють із певною особистістю, уважаючи їх иї «ореолом-іміджем».

Російська дослідниця-політолог Т.Грінберг [5, с. 15] розглядає імідж із позицій його комунікативного та рекламного впливу і тлумачить цей термін як наочний прояв того або іншого фрагменту реальності, котрий утілює рекламну ідею у виразній, нерідко символічній формі, що легко запам'ятовується. На іiі думку, такими проявами можуть бути звукові, зображувальні та вербальні знаки, що втілюють сугестивні завдання рекламного твору. Науковець зауважує, що імідж $є$ цілеспрямовано створюваним образом-уявленням, котрий наділяє об'єкт додатковими цінностями, які власне i сприяють більш емоційному його сприйманню. 
Соціологія розглядає імідж як зовнішній образ, що створюється суб’єктом iз метою справити певне враження, сформувати думку або ставлення інших до себе, а також як сукупність властивостей, приписуваних об'єкту рекламою, пропагандою, модою, забобонами, традицією тощо 3 метою викликати певні реакції відносно нього. Співзвучною із таким визначенням є думка відомого соціолога Е.Гоффмана про те, що імідж - це мистецтво «управляти враженнями».

У сфері маркетингу найпоширенішим є визначення Ф.Котлера [13], згідно 3 яким імідж постає як сприймання компанії або іiі товарів суспільством. Тобто для фахівців цієї галузі науки мірилом ефективності іміджу $є$ зростання продажу товарів, унаслідок чого головний акцент робиться на їх привабливості для покупців.

У галузі менеджменту, а також комунікативних і PR-технологій (зв'язків із громадськістю) поширене подібне тлумачення означеного поняття. Так, російський спеціаліст-менеджер О.Віханський подає загальне визначення іміджу, в якому констатує, що «імідж явища - це стійке уявлення про особливості, специфічні якості й риси, характерні для нього» [3, с. 161].

Крім того, у сфері комунікативних технологій зустрічається використання інструментального підходу, коли поняття іміджу намагаються характеризувати через опис механізмів його функціонування. Так, один із основоположників вітчизняної іміджології, український журналіст та іміджмейкер Г.Почепцов стверджує, що «правильно дібраний імідж є найбільш ефективним способом роботи з масовою свідомістю. Він відображає ті ключові позиції, на які безпомилково реагує масова свідомість» [17, с. 47]. Тому, з точки зору цього науковця, імідж можна розуміти як спробу переведення масової свідомості на автоматичні реакції.

Російський фахівець-іміджмейкер В.Шепель [8] зазначає, що в політичній рекламі й шоу-бізнесі імідж часто постає як образ, наділений характеристиками, що лежать за межами душевної сутності особистості. Тому, на його думку, невипадковим $\epsilon$ той факт, що імідж розуміють як «легенду» або як ідола часу, а менеджмент іміджу полягає у ретельній і постійній роботі над ним із урахуванням постійно змінюваних соціальних і культурних запитів.

Інтерес представників психології та педагогіки до іміджології сприяв виокремленню нової наукової галузі - педагогічної іміджології та предмета іï дослідження - педагогічного іміджу. Учені по-різному тлумачать це поняття. Так, Н.Гузій трактує його як «полісемантичну категорію, що характеризує стиль професійно-педагогічної діяльності, манеру спілкування, уміння індивідуалізувати свій образ, надавати йому естетичної виразності» [6].

Схожої позиції дотримується А.Калюжний, який пропонує розглядати імідж як «стереотип образу педагога в уявленні учнів, колег і соціального оточення», «символічний образ суб’єкта, який створюється в процесі взаємодії педагога з учасниками педагогічного процесу» [10, с. 32-33].

Вагомим складником, своєрідною основою іміджу педагога $\epsilon$ його професійна культура та менталітет. На думку В.Стрельнікова [18], культура педагогічної діяльності вчителя визначає характер його щоденної взаємодії 3 
різними учасниками освітньо-виховного процесу незалежно від розв'язуваних завдань. Виявами такої культури, з позиції дослідника, є особистісні, зокрема моральні, і професійні якості педагога, його вчинки, стиль мовлення, зовнішній вигляд, предметне оточення тощо. У процесі взаємодії вчителя, вихователя із дітьми відбувається трансляція культурних зразків вербальної й невербальної поведінки, способу мислення і т. д. Водночас культура діяльності педагога формує відповідне ставлення учнів, вихованців до його особистості, створює професійний імідж учителя в їх свідомості, який вони передають батькам, одноліткам, іншим педагогам, керівництву освітньої установи.

Дослідники у своїх наукових розвідках звертають увагу на ту особливість, що в іміджі педагога особистісні якості, риси характеру, елементи зовнішнього вигляду тісно переплетені 3 його професійними здібностями. Це дозволяє розглядати педагогічний імідж у двох аспектах - індивідуальному, притаманному кожному окремому педагогові, та в професійному, свого роду образі-зразку представника освітньої галузі.

Український психолог А.Кононенко [12] вивчав індивідуальний імідж педагога. Він, на думку вченого, є проекцією особистості фахівця, що функціонує в процесі соціальних комунікацій, де в зашифрованому вигляді відбиті основні психічні процеси (рівень тривожності, рефлекторного копіювання, емоції тощо). Такий шифр, зауважує дослідник, виявляє себе у вигляді символів на рівні елементарних зовнішніх проявів: постава, мова, міміка, інтонації, тембр голосу тощо. А.Кононенко обстоює думку, що рівень індивідуального іміджу педагога впливає на успішність педагогічної діяльності й несе на собі відбиток змісту його особистості.

Акцентує на можливості професійного іміджу індивідуалізувати й підкреслювати унікальність кожного педагога українська дослідниця О.Ковальова. Зокрема, вона інтерпретує його як «емоційно забарвлений стереотип сприйняття образу вчителя у свідомості вихованців та інших людей, що суттєво відрізняють його від своїх колег» [11, с. 35].

Подібного погляду дотримується й російська дослідниця проблеми формування іміджу викладача вищої школи Л.Донська [7, с. 94]. На її думку, індивідуальний імідж викладача - це гармонійна сукупність зовнішніх і внутрішніх особистісних, індивідних, індивідуальних і професійних якостей педагога, покликаних продемонструвати його бажання, готовність і здатність до суб'єкт-суб'єктного спілкування з учасниками освітнього процесу.

Її колега Т.Бусигіна [2], вивчаючи індивідуальний імідж викладача ВН3, дійшла висновку, що він $є$ соціально-психологічним образом, формування якого обумовлене наявністю яскраво виражених спонтанно або свідомо репрезентованих якостей викладача, що легко сприймаються оточенням під час першого контакту, і який відповідає очікуванням студентської аудиторії та $\epsilon$ передумовою для формування авторитету.

Солідаризується із таким тлумаченням індивідуального іміджу викладача й О.Попова [16]. На іiі думку, індивідуальний імідж конструюється кожним носієм професійного статусу відповідно до власної індивідуальності; у ньому системно відображені індивідуально-особистісні характеристики, фізичні дані, 
соціально-професійні установки, самооцінка, зовнішній стиль, які дозволяють особливим чином репрезентувати вимоги професійного іміджу викладача ВНЗ. Водночас О.Попова подає визначення суто професійного іміджу викладача. Він, на їі погляд, є образом професійної ролі, який конструюється суспільством, трансформується в процесі його якісних змін, сприймається викладачем, утілюється в індивідуальному іміджі в процесі взаємодії зі студентами, колегами, адміністрацією й суспільством, контролюється самим викладачем i громадськістю відповідно до соціально актуальних вимог професії.

Згідно з уявленнями Ж.Попової [15, с. 53] у царині іміджу вчителя початкової школи досліджуване явище охоплює професійний імідж учителя, трансльований соціокультурним контекстом, і персональний імідж учителя, що виражається в індивідуальних психологічних параметрах його особистості та індивідуальному стилі педагогічної діяльності.

Ми цілком поділяємо такі позиції обох дослідниць щодо тлумачення професійного іміджу педагога. Адже кожен носій цього професійного статусу, реалізуючи низку професійних функцій, у власних індивідуальних проявах усіляко намагається відповідати запитам цільової аудиторії, вимогам суспільства, часу і навіть моди.

Підтвердження цього знаходимо у роботі О.Горовенко [4], на думку якої, особистісний імідж учителя зумовлено зовнішніми і внутрішніми факторами, що розкривають його образ на основі особливих індивідуальних якостей i сприяють підвищенню ефективності педагогічної діяльності. Професійний імідж учителя дослідниця розглядає як сукупність особливостей і характерних рис, які формують його образ як фахівця у процесі взаємодії з учнями, колегами, соціальним оточенням. Із цих позицій учена визначає особистіснопрофесійний імідж учителя таким чином: «Цілісний образ особистості педагога, що включає в себе сукупність зовнішніх (габітарний, вербальний, кінетичний, середовищний) та внутрішніх (знання, уміння, здібності, установки, цінності, самооцінка) чинників, особистісних якостей (природні якості; якості, які $\epsilon$ наслідком освіти і виховання; якості, пов'язані із життєвим та професійним досвідом) та засобів самопрезентації, до яких цілеспрямовано звертається учитель 3 метою досягнення найкращих результатів своєї педагогічної діяльності» [4, с. 8].

Українська дослідниця проблеми формування професійно-педагогічного іміджу майбутніх викладачів вищої школи В.Ісаченко, даючи власне визначення поняття «імідж», указує на певну його прагматичність. Так, учена розуміє під професійно-педагогічним іміджем «емоційно забарвлений психічний образ, який склався в масовій свідомості і має характер стереотипу, що легко трактується». Водночас «йому притаманні значні регуляторні властивості, він відчутно впливає на пояснювальні механізми свідомості, поведінки і вибір іншої людини як учасника й споживача сфери освітніх послуг» [9].

Заслуговують на увагу й погляди російської дослідниці проблеми формування іміджу майбутнього педагога-хореографа А.Череднякової [19]. Вона визначає професійний імідж як «цілеспрямовано формований образ 
фахівця, що містить професійно важливі якості, котрі сприяють ефективності суб'єкт-суб'єктної взаємодії в педагогічній діяльності» [19, с. 41]. На думку вченої, професійний імідж не дається від природи, а набувається і вдосконалюється у процесі всього життя людини, залученої до тієї чи іншої професійної діяльності. Професійний імідж, стверджує вона, формується у процесі зовнішньої діяльності, яка організується, з одного боку, професійною освітньою установою, і з другого, систематичною цілеспрямованістю роботи самої особистості з оволодіння професією.

Погоджуючись із позицією дослідниці, зауважимо, що, дійсно, виникнення і розвиток професійного іміджу фахівця будь-якої сфери діяльності, зокрема вихователя дітей дошкільного віку, стають можливими тільки під впливом професійної діяльності, яка стає його умовою та показником.

Що стосується іміджу вихователя дошкільного навчального закладу, то М.Апраксіна [1, с. 106] розуміс його як цілеспрямоване створення візуальноаудіального образу педагога, який дозволяє найбільш вигідно й привабливо проявитися найкращим особистісно-діловим якостям фахівця. С.Попиченко [14] дещо розширює i доповнює таке тлумачення іміджу вихователя i виокремлює в ньому такі складники: зовнішній вигляд, внутрішній образ та професійно-педагогічне спілкування. На їі думку, зовнішній вигляд передбачає не лише вміння правильно одягатися, але й здатність демонструвати свій розум, професійні навички і здібності, виявляти любов до дітей і турботу про них. Внутрішній образ представлений культурою педагога, його установками, поглядами, характером, емоційним ставленням до дійсності. I нарешті, професійно-педагогічне спілкування, яке, на думку С.Попиченко, є підгрунтям виховання, що дає змогу цілеспрямовано реалізовувати комплекс заходів щодо формування гармонійно розвиненої особистості вихованців.

Ми частково погоджуємося із таким структуруванням професійного іміджу вихователя ДНЗ дослідницею і пропонуємо виокремити такі компоненти в ньому: візуальний (зовнішній вигляд, невербальні засоби комунікації, предметне середовище вихователя), аудіальний (володіння технікою та комунікативними якостями мовлення, ораторським мистецтвом), професійний (компетентність вихователя, якість його праці в цілому, досвід, репутація, вміння самовдосконалюватися) та внутрішній (педагогічна спрямованість, психічне й психологічне, соціальне і духовне здоров'я, особистісно-професійні якості педагога). Пропоновану нами структуру професійного іміджу вихователя ДНЗ подано на рис. 1.

Усі компоненти професійного іміджу вихователя ДНЗ у сукупності й кожен зокрема є соціально зумовленими і соціально зорієнтованими водночас. Пояснюємо це тим, що формування i розвиток будь-якого із компонентів професійного іміджу вихователя ДНЗ залежить від соціального оточення, а також поглядів, цінностей, уподобань, смаків, еталонів тощо, що переважають у ньому. Адже кожен із визначених складників іміджу більшою або меншою мірою зазнає змін і трансформацій залежно від тих вимог, які висуваються різними суб'єктами освітньої взаємодії - дітьми, їхніми батьками, колегами й керівництвом ДНЗ, громадськістю тощо, та тих, які висуває до себе педагог. 


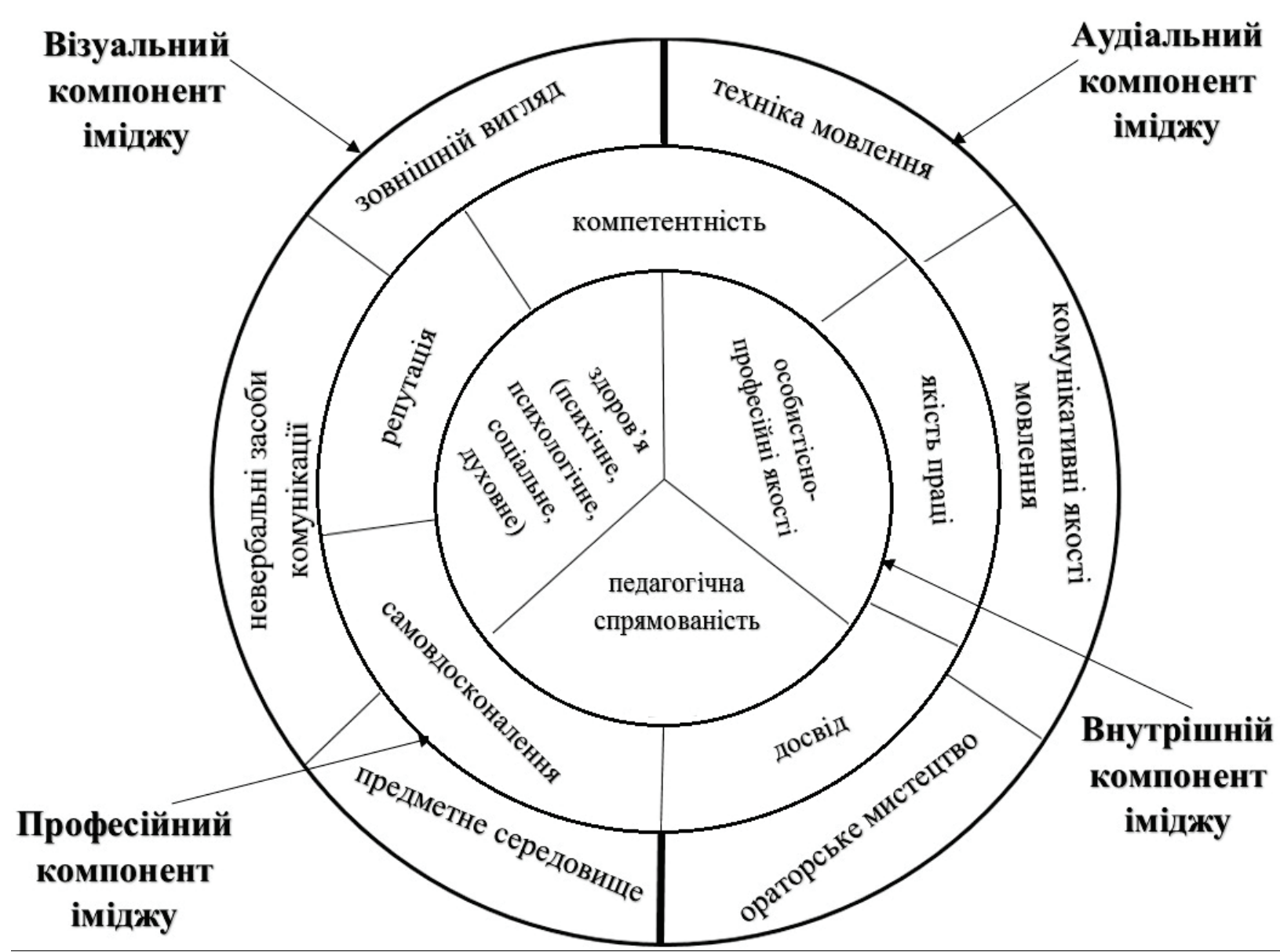

Рис. 1. Структура професійного іміджу вихователя ДНЗ

Ядром іміджу, яке вирізняється відносною статичністю, є його внутрішній компонент. Набувається він у процесі соціалізації та виховання людини i частково в процесі здобуття педагогічної освіти.

На внутрішній нашаровується професійний компонент іміджу педагога дошкільного профілю, котрий безпосередньо виявляється у різноманітних ситуаціях взаємодії з цільовою аудиторією. Він є динамічнішим порівняно 3 внутрішнім, формується під впливом цілеспрямованої професійної підготовки та в процесі безпосередньої практичної діяльності за фахом. При цьому, грунтуючись на особистісно-професійних якостях вихователя, його спрямованості, стані психічного, психологічного, соціального i духовного здоров'я, професійний складник іміджу піддається частковій трансформації залежно від вимог, що висувають його реципієнти, тобто від тих, хто його сприймає, а також від прагнення самого носія іміджу, тобто педагога, працювати над собою, професійно вдосконалюватися.

Найбільшою динамічністю, на нашу думку, характеризуються візуальний та аудіальний компоненти іміджу вихователя.

У процесі взаємодії з різними учасниками освітньо-виховного процесу в ДНЗ, як нам видається, розкриваються внутрішній і професійний компоненти іміджу вихователя, які й визначають успішність реалізації його професійних функцій. Це виявляється в його майстерності та відбивається на сприйнятті 
педагога дітьми, їхніми батьками, колегами, керівництвом ДНЗ, громадськістю в цілому як компетентного фахівця, тобто на його іміджі.

Виходячи із такого структурування професійного іміджу вихователя ДНЗ, можемо запропонувати власне визначення цього поняття. Пропонуємо тлумачити його як якісну характеристику особистості педагога, що сприяє прояву іiі внутрішніх установок, особистісних якостей, життєвих позицій, знань і професіоналізму через зовнішні виразники - зовнішній вигляд, поведінку, особливості вербального і невербального спілкування, специфіку оформлення рукотворного середовища, які суттєво впливають на організацію міжособистісної взаємодії та реалізацію професійних функцій фахівця.

Загалом зауважимо, що імідж вихователя ДНЗ виникає й, відповідно, існує незалежно від того, хоче цього педагог чи ні. Тобто імідж може створюватися сам собою, стихійно, у процесі взаємодії 3 дітьми, їхніми батьками, вихователями або ж цілеспрямовано. При цьому полюс іміджу вихователя може бути як позитивним, так і негативним.

Висновки 3 дослідження і перспективи подальших досліджень. Отже, професійний імідж вихователя ДНЗ характеризується поєднанням внутрішньої сутності педагога із засобами іiі зовнішнього втілення (зовнішнього вигляду, стилю спілкування і поведінки тощо). Складниками професійного іміджу вихователя ДНЗ є: візуальний, аудіальний, внутрішній і професійний. Кожен із них має своє специфічне наповнення і $€$ вагомим елементом у загальній структурі професійного іміджу педагога дошкільного профілю. Подальші дослідження стосуватимуться вивчення типів професійного іміджу вихователя ДНЗ та особливостей їх вияву в його фаховій діяльності.

\section{Література:}

1. Апраксина М. В. Имидж воспитателя дошкольного учреждения как педагогическая проблема : дисс. ... кандидата пед. наук : 13.00 .01 / Маргарита Владимировна Апраксина. - Москва, 2000. - 134 с.

2. Бусыгина Т. А. Индивидуальный имидж как социально-перцептивный компонент профессиональной компетентности преподавателя вуза : автореф. дисс. на соискание учен. степени канд. психол. наук : спец. 19.00.05 «Социальная психология» / Татьяна Александровна Бусыгина. - Самара, 2004. $-24 \mathrm{c}$.

3. Виханский О. С. Стратегическое управление / Олег Самуилович Виханский. - Москва : Гардарика, 2002. - 296 с.

4. Горовенко О. А. Формування особистісно-професійного іміджу вчителя загальноосвітнього навчального закладу засобами самопрезентації : автореф. дис. на здобуття наук. ступеня канд. пед. наук : спец. 13.00.04 «Теорія i методика професійної освіти» / Оксана Анатоліївна Горовенко. - ПереяславХмельницький, 2013. - 20 с.

5. Гринберг Т. Политическая реклама: портрет лидера / Т. Гринберг. Москва : Прогресс, 1995. - 103 с.

6. Гузій Н. В. Педагогічний імідж і професійна культура вчителя / Н. В. Гузій // Творча особистість вчителя: проблеми теорії і практики : зб. наук. 
праць. - Київ : НПУ, 1997. - С. 28-31.

7. Донская Л. Ю. Психологические условия формирования имиджа преподавателя высшей школы : дисс. ... кандидата психол. наук : 19.00 .07 / Лариса Юрьевна Донская. - Ставрополь, 2004. - 212 с.

8. Имиджелогия: Как нравиться людям / [сост., науч. ред. Шепель В. М.]. - Москва : Народное образование, 2002. - 576 с.

9. Ісаченко В. В. Формування професійно-педагогічного іміджу майбутніх викладачів вищої школи : дис. ... кандидата пед. наук : 13.00 .04 / Вікторія Володимирівна Ісаченко. - Одеса, 2004. - 215 с.

10. Калюжный A. А. Психология формирования имиджа учителя / Анатолий Афанасьевич Калюжный. - Москва : Гуманитар. изд. центр ВЛАДОС, 2004. - 222 с. - (Библиотека руководителя образовательного учреждения).

11. Ковальова О. О. Психологічні особливості формування основ професійного іміджу у майбутніх педагогів : дис. ... кандидата психол. наук : 19.00.07 / Олена Олександрівна Ковальова. - Одеса, 2007. - 340 с.

12. Кононенко А. О. Психологічні складові індивідуального іміджу сучасного педагога : автореф. дис. на здобуття наук. ступеня канд. психол. наук : спец. 19.00.07 «Педагогічна та вікова психологія»/ Анатолій Олександрович Кононенко. - Одеса, 2003. - 20 с.

13. Котлер Ф. Основы маркетинга. Краткий курс / Филипп Котлер ; [пер. с англ. издательства «Прогресс»]. - Москва : Издательский дом «Вильямс», 2007. $-656 \mathrm{c}$.

14. Попиченко С. Роль комунікативної компетенції в технології створення іміджу педагога-вихователя дошкільного навчального закладу [Електронний pecypc] / С. Попиченко // Психолого-педагогічні проблеми сільської школи. 2012. - № 41. - С. 53-58. - Режим доступу : http://nbuv.gov.ua/jpdf/Ppps_2012_41_9.pdf. - Назва 3 екрана. (Дата звернення: $21.10 .2016)$.

15. Попова Ж. Г. Социально-психологические особенности представлений об имидже учителя начальной школы : дисс. ... кандидата психол. наук : 19.00.05 / Жанна Георгиевна Попова. - Москва, 2007. - 198 с.

16. Попова О. И. Имидж преподавателя вуза: проблема трансформации в современной России : дисс. ... кандидата социол. наук : 22.00.04 / Ольга Ивановна Попова. - Екатеринбург, 2007. - 152 с.

17. Почепцов Г. Г. Имиджелогия / Георгий Георгиевич Почепцов. - 2-е изд., испр. и доп. - Москва : Рефл-бук ; Киев : Ваклер, 2001. - 698 с.

18. Стрельніков В. Ю. Педагогічна культура - основа іміджу сучасного педагога / В. Ю. Стрельніков // Імідж сучасного педагога. - 2000. - № 4-5. С. 6-8.

19. Череднякова А. Б. Формирование имиджа будущего педагогахореграфа в ВУЗе культуры : дисс. ... кандидата пед. наук : 13.00 .05 / Анна Борисовна Череднякова. - Екатеринбург, 2006. - 208 с.

Стаття надіслана: 08.06.2017 p.

(C) Марєєва Т. В. 